Predrag Čudina

Ana Bezić

http://dx.doi.org/10.21278/brod70109

ISSN 0007-215X

eISSN 1845-5859

\title{
REEFER VESSEL VERSUS CONTAINER SHIP
}

UDC 629.5(05):629.542.4:6295.544

Professional paper

\begin{abstract}
Summary
In the paper is presented a study of the economics of refrigerated cargoes transport with two specialized types of ship. Two modern ship designs are developed for the transport of refrigerated cargo, primarily bananas. One design is a reefer vessel with the ability to load a significant number of refrigerated containers on the main deck. The other design is a container ship specialized for the transport of refrigerated 40 feet containers. Both designs have the capacity to load the same mass of refrigerated cargo. Basic characteristics of the designs are compared, which can be the basis for answering the question: Which type of vessel to choose for the carriage of refrigerated cargo?
\end{abstract}

Key words: $\quad$ refrigerated vessel; container ship; ship design

\section{Introduction}

In recent years a dilemma has emerged: Is it more economical to transport refrigerated cargoes with reefer vessels or container ships? Development of different ship designs dedicated for transportation of refrigerated cargoes is elaborated in [1], where reefer ships are divided on traditional reefer ship for carriage of reefer cargoes in bulk, pure pallet ships and freezers.

In [2] container ships are, for quite understandable reasons, included in the family of "Linear Dimension" ships. Later, the same author in [3] includes container ships in the family of "Volume, Area and Dimension-Based Design" ships. In [1] container ships dedicated for transport large number of refrigerated containers are defined as separate ship type, commonly referred to as "Reefer Containers".

Over time, the design of reefer vessels is developing in the direction of loading more and more containers in the cargo holds and on the main deck, so the differences between these two types are increasingly reduced. Also, both types have their own unique characteristics, so it can be said that each type has a number of differences (resulting as advantages or disadvantages) over the other type of ship. 


\section{Basic Design Requirements}

Both designs have been developed under the same basic design requirement: to be able to load 12,000 t of refrigerated cargo. Also, both designs have been developed with the intent of loading the maximum number of (exclusively) refrigerated containers. Designs development was carried out in close cooperation with the specialised shipping companies based on "traditional" ship design spiral method. Speed-power calculation was carried out following the speed-power approximation method published in $[4,5]$, modified for design of reefer vessel and container ship. Special attention has been paid to energy efficiency and all related aspects $[5,6]$. Basic design requirements are as follows:

- Cargo: abt. 11,440 high-cube (height $2.4 \mathrm{~m})$ EURO pallets $(1.2 \times 1.0 \mathrm{~m})$

- Maximum draught $11.0 \mathrm{~m}$

- Main engine MAN B\&W8G50ME-C9.6 Tier III

- Selected maximum continuous rating (SMCR) 11,980 kW at $100 \mathrm{rpm}$

- Continuous service rating $(\mathrm{CSR})=90 \%$ SMCR

- 40 feet ISO refrigerated high-cube containers (40' x 8' x 9.5')

- Electrical sockets for all deck containers

- Electrical sockets for all containers in cargo holds

- Accommodation for 25 crew +6 Suez crew

Additional requirements for reefer vessel:

- Dimension of EURO pallet with stowage margin: $1.24 \times 1.03 \mathrm{~m}$

- Clear tween deck height $2.55 \mathrm{~m}$

- Aluminium gratings height $150 \mathrm{~mm}$

- 4 cargo holds, 16 compartments, 8 independent cooling zones

- 2 twin deck cranes, each 2 x 20 t SWL

- Cargo hatch covers of folding type

- Cargo holds air recirculation

Additional requirements for container ship:

- 4 single deck cranes, each 40 t SWL

- Cargo hatch covers of pontoon type

- Cargo holds ventilation

\section{Basic Design of P105 Reefer Vessel 765,000 cu.ft.}

Based on the design requirements, a modern design of container-oriented reefer vessel is developed. She is a single screw diesel engine driven Reefer/Container Vessel with bulbous bow, long forecastle, poop deck and transom stern, Figures 1 and 2. Living quarters including navigation bridge and engine room located aft. Double bottom, bilge and peak tanks intended for segregated ballast. Cargo space divided into four (4) cargo holds subdivided into eight (8) refrigerated compartments with separate air cooling.

Intended cargo: $\quad$ Bananas, fruit, frozen meat, fish, palletized cargo, 40 feet containers

Main particulars:

Length overall abt. $178.6 \mathrm{~m}$

Length b.p. $168.0 \mathrm{~m}$

Breadth, mld. $27.2 \mathrm{~m}$

Depth, mld. $15.0 \mathrm{~m}$

Draught design $8.8 \mathrm{~m}$

Draught scantling $11.0 \mathrm{~m}$

Deadweight design . abt. $13,400 \mathrm{t}$

Deadweight scantling abt. $21,400 \mathrm{t}$ 
Capacities:

Refrigerated cargo holds, total

abt. 850,000 cu.ft.

Refrigerated cargo holds (up to $2.55 \mathrm{~m}$ height)

abt. 765,000 cu.ft.

Cargo deck area, total abt. $8,550 \mathrm{~m}^{2}$

Number of Euro pallets (1.2 m x $1.0 \mathrm{~m})$ abt. 6,600 pcs

Number of containers, holds/deck abt. 82/242 FEU

Heavy fuel oil abt. $1,800 \mathrm{~m}^{3}$

MGO/MDO abt. $\quad 370 \mathrm{~m}^{3}$

Fresh water abt. $200 \mathrm{~m}^{3}$

Feed water abt. $\quad 40 \mathrm{~m}^{3}$

Segregated water ballast, total abt. $6,000 \mathrm{~m}^{3}$

Cruising range abt. 18,000 n. miles

Main engine:

MAN-B\&W 8G50ME-C9.6 Tier III

\section{SMCR 11,980 kW at $100 \mathrm{rpm}$, CSR $10,780 \mathrm{~kW}$}

Guaranteed speed: $\quad 21.0$ knots in trial conditions, design draught and CSR, i.e. $10,780 \mathrm{~kW}$

M.e. consumption: abt. $42.4 \mathrm{t} /$ day of fuel oil LCV $42,707 \mathrm{~kJ} / \mathrm{kg}$

Basic loading conditions are shown in the following table.

Table 1 Basic Loading Conditions of P105

\begin{tabular}{|l|c|c|}
\hline Loading condition & Payload (t) & $\begin{array}{c}\text { Mean draught } \\
\text { departure/arrival (m) }\end{array}$ \\
\hline $\begin{array}{l}\text { Banana pallets }(6,600 \mathrm{pcs})+242 \text { deck FEU (each } \\
28 \mathrm{t})\end{array}$ & $6,930+6,776$ & $11.0 / 10.5$ \\
\hline 82 FEU in holds + 224 deck FEU (each 28 t) & $2,296+6,272$ & $9.7 / 9.2$ \\
\hline Loading condition: design draught & Payload (t) & Mean draught $(\mathrm{m})$ \\
\hline $\begin{array}{l}\text { Banana pallets }(6,600 \text { pcs })+150 \text { FEU (each } 28 \mathrm{t}) \\
+25 \% \text { stores }\end{array}$ & $6,930+4,200$ & 8.8 \\
\hline
\end{tabular}

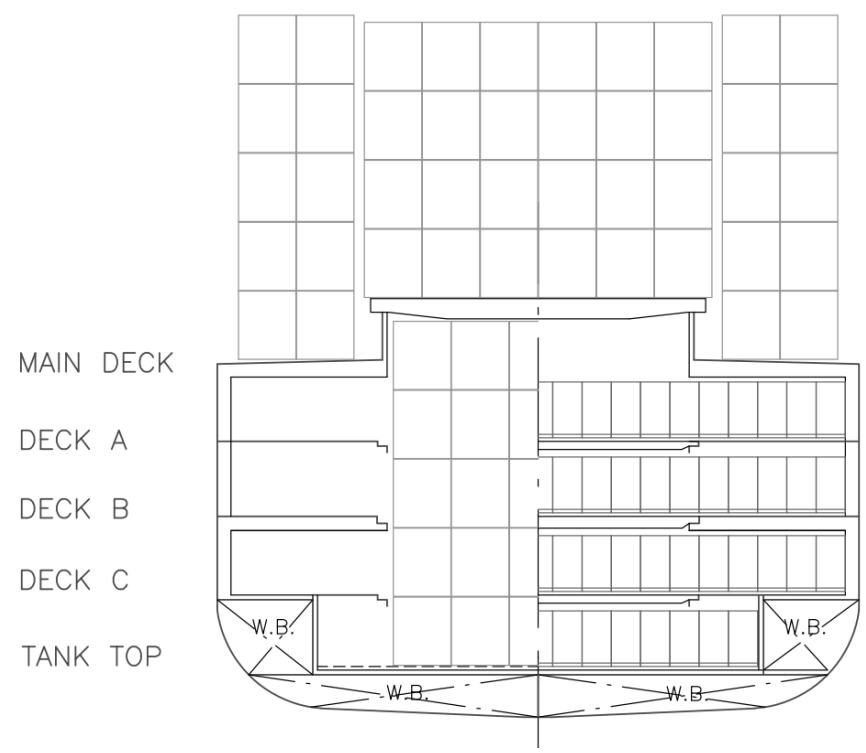

Fig. 1 Midship Section of P105 

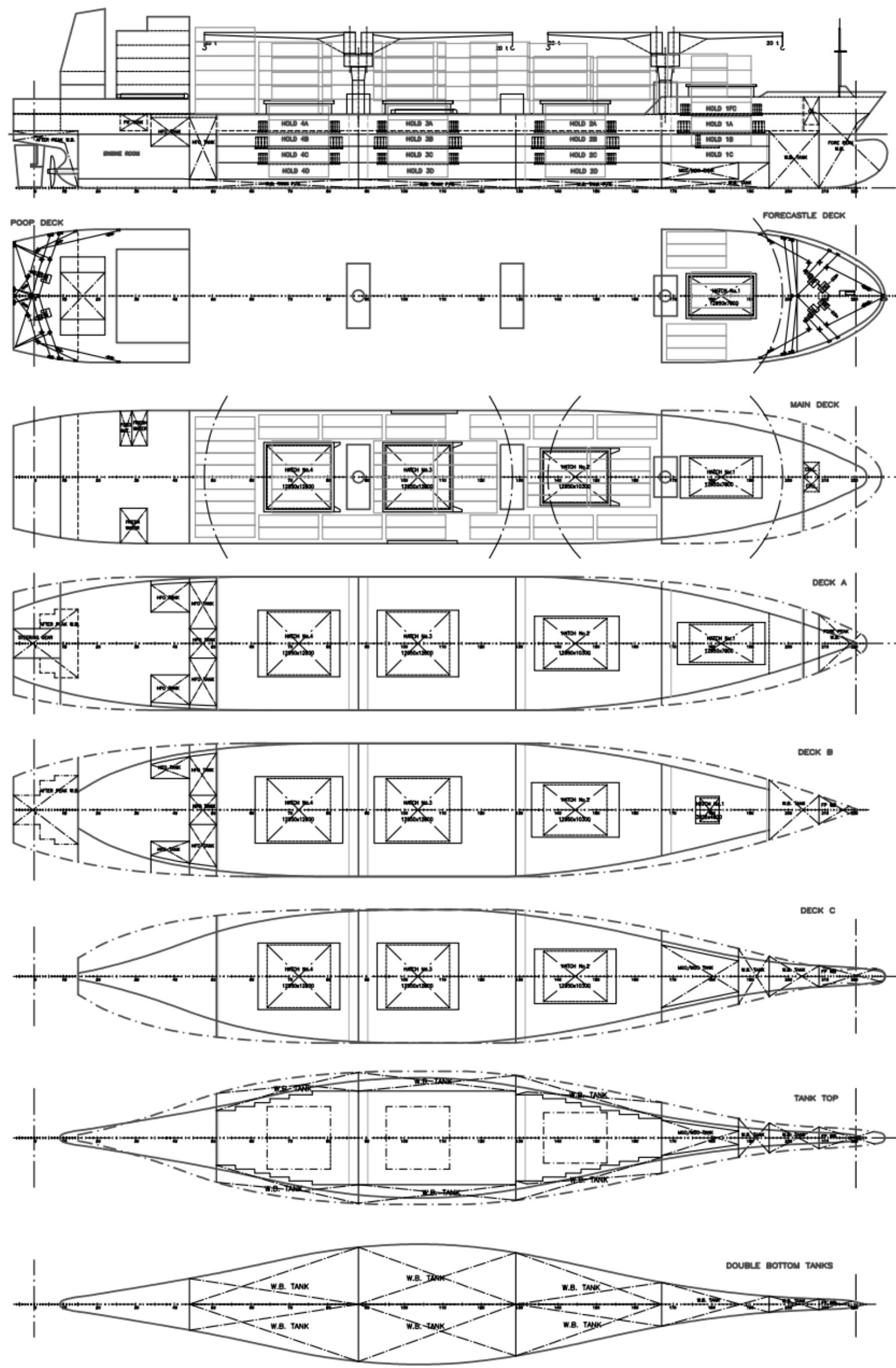

Fig. 2 General Arrangement of P105 


\section{Basic Design of P109 Container Ship 742 FEU}

Based on the design requirements, a modern design of Container Ship specialized for loading 40' refrigerated containers is developed. She is a single screw diesel engine driven Container Ship with bulbous bow, long forecastle, poop deck and transom stern. Living quarters including navigation bridge and engine room located aft, Figures 3 and 4. Double bottom, double side and peak tanks intended for segregated ballast. Cargo space divided into four (4) cargo holds.

Intended cargo: $\quad$ Refrigerated 40' ISO high-cube containers (40' x 8' x 9.5')

Main particulars:

Length overall abt. $177.0 \mathrm{~m}$

Length b.p. $166.0 \mathrm{~m}$

Breadth, mld $27.5 \mathrm{~m}$

Depth, mld. $15.0 \mathrm{~m}$

Draught design $9.5 \mathrm{~m}$

Draught scantling $11.0 \mathrm{~m}$

Deadweight design abt. $17,800 \mathrm{t}$

Deadweight scantling abt. $23,700 \mathrm{t}$

Capacities:

Cargo holds, total abt. $30,000 \mathrm{~m}^{3}$

Number of $28 \mathrm{t}$ refrigerated containers, holds/deck

Heavy fuel oil abt. $269 / 303 \mathrm{FEU}$

MGO/MDO abt. $1,650 \mathrm{~m}^{3}$

Fresh water abt. $\quad 500 \mathrm{~m}^{3}$

Feed water abt. $200 \mathrm{~m}^{3}$

Segregated water ballast, total abt. $\quad 40 \mathrm{~m}^{3}$ Cruising range abt. $8,700 \mathrm{~m}^{3}$

Main engine:

$$
\begin{aligned}
& \text { MAN-B\&W 8G50ME-C9.6 Tier III } \\
& \text { SMCR 11,980 kW at } 100 \mathrm{rpm}, \text { CSR 10,780 kW }
\end{aligned}
$$

Guaranteed speed: $\quad 19.4$ knots in trial conditions, design draught and CSR, i.e. 10,780 kW M.e. consumption: abt. $42.4 \mathrm{t} /$ day of fuel oil LCV $42,707 \mathrm{~kJ} / \mathrm{kg}$

Basic loading conditions are shown in the following table.

Table 2 Basic Loading Conditions of P109

\begin{tabular}{|l|c|c|}
\hline Loading condition: scantling draught & Payload $(\mathrm{t})$ & $\begin{array}{c}\text { Mean draught } \\
\text { departure/arrival }(\mathrm{m})\end{array}$ \\
\hline 269 FEU in holds + 303 deck FEU (each 28 t) & 16,016 & $11.0 / 10.6$ \\
\hline Loading condition: design draught & Payload $(\mathrm{t})$ & Mean draught $(\mathrm{m})$ \\
\hline $\begin{array}{l}\text { 269 FEU in holds }+241 \text { deck FEU (each 28 t) }+ \\
\text { 25\% stores }\end{array}$ & 14,280 & 9.5 \\
\hline
\end{tabular}



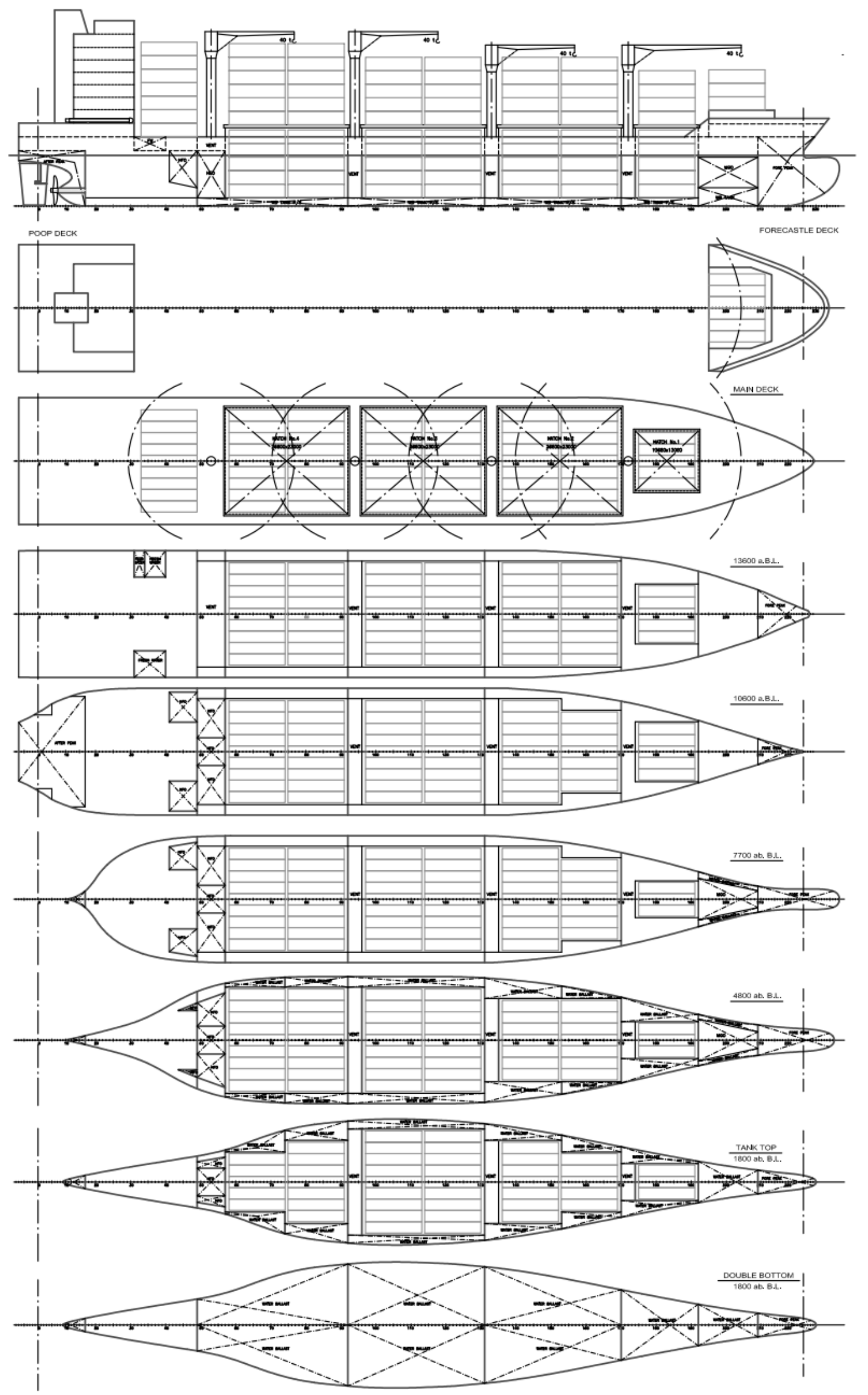

Fig. 3 General Arrangement of P109 


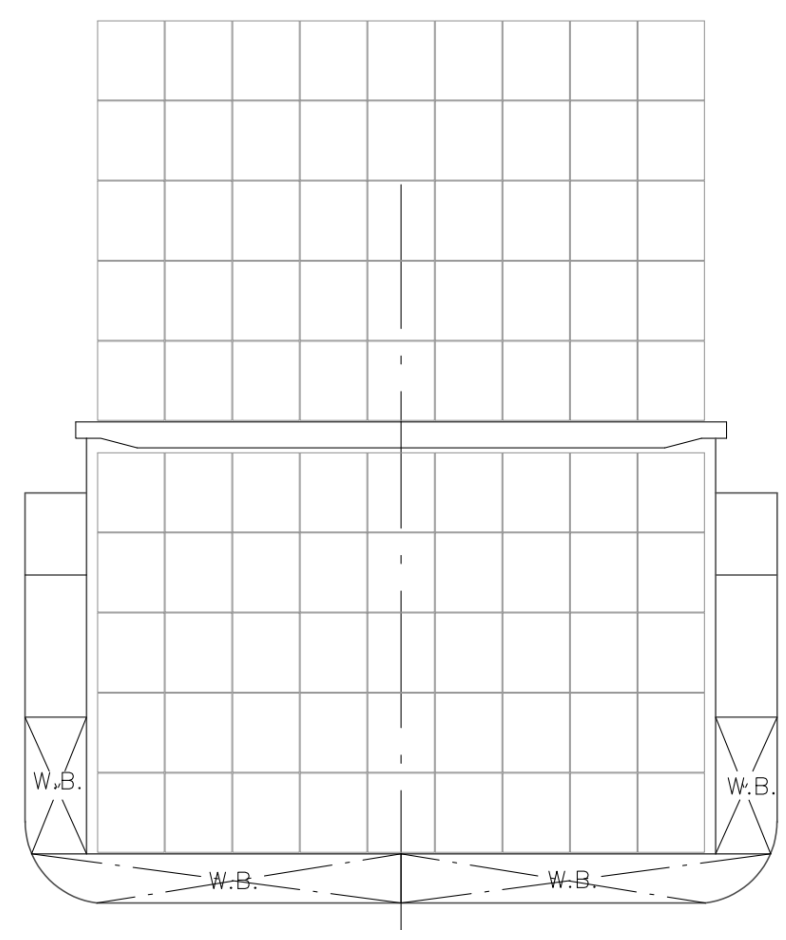

Fig. 4 Midship Section of P109

\section{Comments on Designs}

Both designs have a number of similar characteristics: main dimensions are almost the same, general configuration is very similar: four cargo holds, long forecastle, poop deck, accommodation situated aft.

The designs differ in characteristics that are specific to each type of ship. Reefer vessel has two $2 \times 20$ t SWL twin deck cranes and folding type hatch covers. Container ship is equipped with four $40 \mathrm{t}$ SWL single deck cranes and pontoon type hatch covers. Reefer vessel loads palletized cargo on tank top and three tween decks. Alternatively, 5 tiers of high-cube FEU can be loaded on the tank top. Container ship also can load in cargo holds 5 tiers of highcube FEU.

When comparing these two designs, attention should be paid to a very significant difference: in a case of a reefer vessel payload consists of palletized cargo and containers, but in a case of container vessel the payload consists exclusively of containers. What that means?

One high-cube FEU can be loaded with 20 high-cube EURO pallets. If bananas are loaded, each pallet has a mass of abt. 1.05 t. The gross mass of loaded refrigerated container is abt. $28 \mathrm{t}$ and net mass of pallets is abt. $20 \times 1.05=21 \mathrm{t}$. It leads to a result that container ship when loading 11,440 banana pallets (572 FEU x 20 pallets), loads cargo mass of 16,016 t (572 FEU x $28 \mathrm{t}$ ).

Reefer vessel, when loading banana pallets in cargo holds plus refrigerated FEU on the main deck, loads cargo mass of $6,930 \mathrm{t}(6,600$ pallets $\mathrm{x} 1.05)$ plus cargo mass of $6,776 \mathrm{t}$ (242 FEU x $28 \mathrm{t}$ ). In total, it loads cargo mass of 13,706 t, which is 2,310 t less than the cargo mass loaded by the container ship. Thereby, both ships load the same quantity of banana pallets, totally 11,440 pieces. 


\section{Analysis of the Economy of Ships in Navigation}

Analysis is carried out for the case of fully loaded ships in navigation and for the case of sailing in the ballast condition. Since the purpose of this paper is to carry out a comparison of two ship design dedicated for carriage of refrigerated cargoes, rather than the total economy of shipping company, the analysis is limited to the fuel costs of a voyage. In addition, it is important to note that fuel cost is the dominant item in the voyage costs [8].

\subsection{Fully Loaded Ships}

Both ships are fully loaded to the scantling draught and are observed under the following conditions:

- Ships are fully loaded on scantling draught

- Ships are sailing at the same speed in the service conditions (15\% sea margin)

- Consumption of each refrigerated FEU is $7 \mathrm{~kW}$, diversity factor is 0.7

- Consumption of reefer vessel refrigerating plant is $700 \mathrm{~kW}$

- Cooling down period for bananas is $24 \mathrm{~h}$ (1 day) for reefer vessel

- Consumption of reefer vessel refrigerating plant during cooling down period is 1,400 $\mathrm{kW}$

- Consumption of reefer vessel cargo holds ventilation / air recirculation is $500 \mathrm{~kW}$

- Consumption of container ship cargo holds ventilation is $500 \mathrm{~kW}$

- Consumption of other consumers is $650 \mathrm{~kW}$

For the purpose to determine needed main engine power for both ships, following speed-power estimations are carried out using methodology published in [9] and correlated with results of prototype ship model testing $[10,11]$.

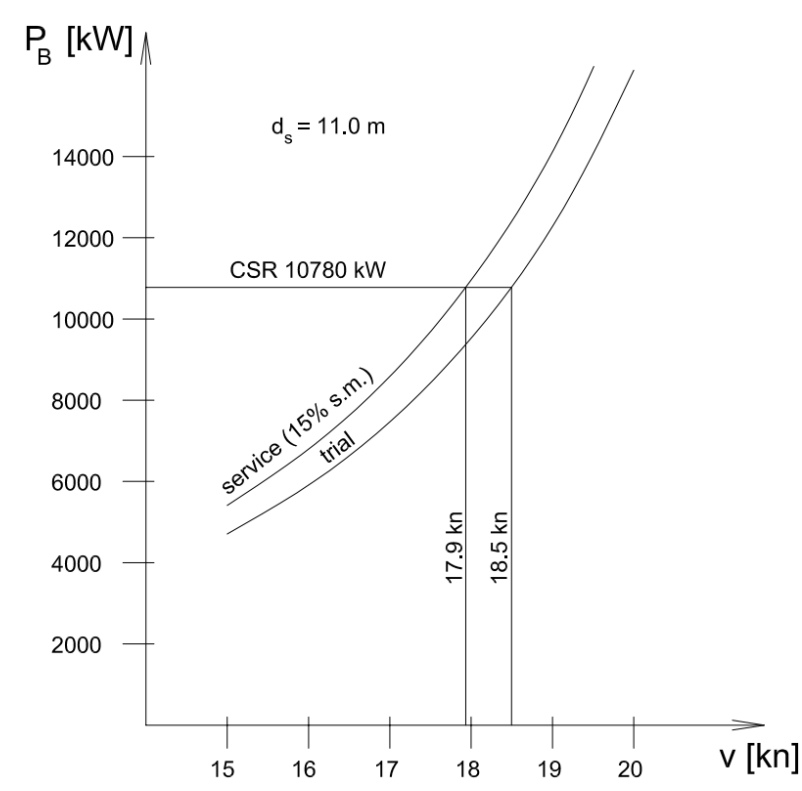

Fig. 5 Speed-Power Estimation of P109 (Container Ship) on Scantling Draught

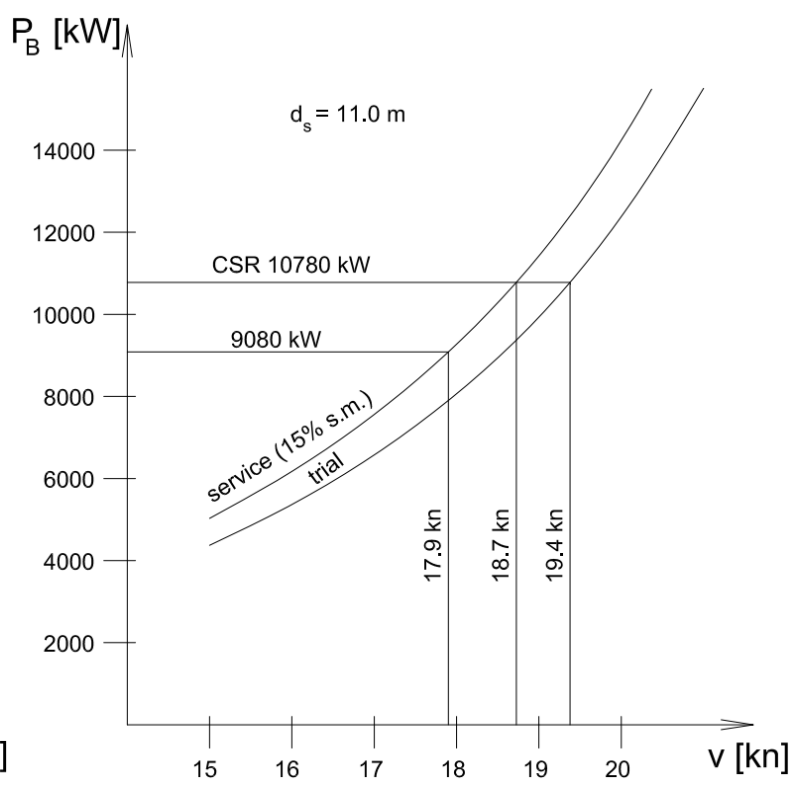

Fig. 6 Speed-Power Estimation of P105 (Reefer Vessel) on Scantling Draught

Calculation of daily fuel oil consumption for both ships is carried out and shown in Tables 3 through 5. It is based on the declared conditions and needed main engine power for service speed of 17.9 knots. Reefer vessel cargo refrigerating plant during cooling down period is consuming $1,400 \mathrm{~kW}$ (instead of $700 \mathrm{~kW}$ during the period after cooling down ends), Figures 5 and 6. 
Table 3 Basic Electric Power Calculation

\begin{tabular}{|l|c|c|c|r|c|c|c|r|}
\hline & \multicolumn{4}{|c|}{ P105 (Reefer Vessel) } & \multicolumn{3}{c|}{ P109 (Container Ship) } \\
\hline \multirow{3}{*}{ Consumer } & $\begin{array}{l}\text { No } \\
\text { of }\end{array}$ & $\begin{array}{c}\text { Peak } \\
\text { load }\end{array}$ & $\begin{array}{c}\text { Div. } \\
\text { factor }\end{array}$ & Power & $\begin{array}{c}\text { No } \\
\text { of }\end{array}$ & $\begin{array}{c}\text { Peak } \\
\text { load }\end{array}$ & $\begin{array}{c}\text { Div. } \\
\text { factor }\end{array}$ & Power \\
\hline$[-]$ & {$[\mathrm{kW}]$} & {$[-]$} & {$[\mathrm{kW}]$} & {$[-]$} & {$[\mathrm{kW}]$} & {$[-]$} & {$[\mathrm{kW}]$} \\
\hline Cargo refrigerating plant & 1 & 700 & 1.0 & 700 & 1 & & & \\
\hline Refrig. during cool. down & 1 & 1,400 & 1.0 & 1,400 & & & & \\
\hline Holds vent./air circulation & 1 & 500 & 1.0 & 500 & 1 & 500 & 1.0 & 500 \\
\hline Refrigerated FEU & 242 & 7 & 0.7 & 1,186 & 572 & 7 & 0.7 & 2,803 \\
\hline Other consumers & 1 & 650 & 1.0 & 650 & 1 & 650 & 1.0 & 650 \\
\hline Total during sailing & & & & 3,036 & & & & 3,953 \\
\hline Total: sailing + cool. down & & & & 3,736 & & & & \\
\hline
\end{tabular}

Table 4 Daily Fuel Oil Consumption of Fully Loaded Ships

\begin{tabular}{|l|c|c|c|c|c|c|}
\hline & \multicolumn{3}{|c|}{ P105 (Reefer Vessel) } & \multicolumn{3}{c|}{ P109 (Container Ship) } \\
\hline \multirow{2}{*}{ Consumer } & Power & sfoc & dfoc & Power & sfoc & dfoc \\
\cline { 2 - 8 } & {$[\mathrm{kW}]$} & {$[\mathrm{g} / \mathrm{kWh}]$} & {$[\mathrm{t} / \mathrm{day}]$} & {$[\mathrm{kW}]$} & {$[\mathrm{g} / \mathrm{kWh}]$} & {$[\mathrm{t} / \mathrm{day}]$} \\
\hline Main engine & 9,080 & 158.3 & 34.5 & 10,780 & 162.0 & 41.9 \\
\hline Diesel generator plant & 3,036 & 192.0 & 14.0 & 3,953 & 192.0 & 18.2 \\
\hline DG plant during cool. down & 3,736 & 192.0 & 17.2 & & & \\
\hline Total (LCV=42,700 kJ/kWh) & & & 48.5 & & & 60.1 \\
\hline Total: sailing + cool. down & & & 51.7 & & & \\
\hline Total (HFO) & & & 51.4 & & & 63.7 \\
\hline Total: sail.+cool.down (HFO) & & & 54.8 & & & \\
\hline
\end{tabular}

It can be noticed that there is a significant difference in fuel oil consumption between reefer vessel and container ship. Calculation of fuel oil consumption in the case of an assumed route of 5,000 nautical miles (days in navigation $=5,000 \mathrm{~nm} / 17.9 \mathrm{kn} / 24 \mathrm{~h} /$ day $\approx 12$ days) is as follows.

Table 5 Total Fuel Oil Consumption of Fully Loaded Ships

\begin{tabular}{|l|c|c|c|}
\hline & Duration & $\begin{array}{c}\text { Daily fuel oil } \\
\text { consumption }(\mathrm{dfoc})\end{array}$ & $\begin{array}{c}\text { Total fuel oil } \\
\text { consumption }\end{array}$ \\
\cline { 2 - 4 } & {$[$ days] } & {$[\mathrm{t} /$ day] } & {$[\mathrm{t}]$} \\
\hline \multirow{3}{*}{ P105 (Reefer Vessel) } & 1 & 54.8 & 54.8 \\
\cline { 2 - 4 } & 11 & 51.4 & 565.4 \\
\hline & & & $\sim 620$ \\
\hline P109 (Container Ship) & 12 & 63.7 & $\sim 764$ \\
\hline
\end{tabular}

Difference of total fuel consumption is abt. $144 \mathrm{t}$. If we assume a heavy fuel oil price of abt. 400-420 US\$/t, saving of reefer vessel in comparison with container ship is abt. 60,000 US\$ for 12 days sailing in a fully loaded condition. 


\subsection{Ships Sailing on Ballast Draught}

Both ships are loaded to the ballast draught and are observed under the following conditions:

- Both ships are sailing on ballast draught that ensure good propeller immersion

- Ships are sailing at the same speed in the service conditions (15\% sea margin)

- Load of diesel-generator plant is $650 \mathrm{~kW}$

For the purpose to determine needed main engine power for both ships, speed-power estimations are carried out. Achievable speeds in both trial and service condition are shown in Figures 7 and 8.

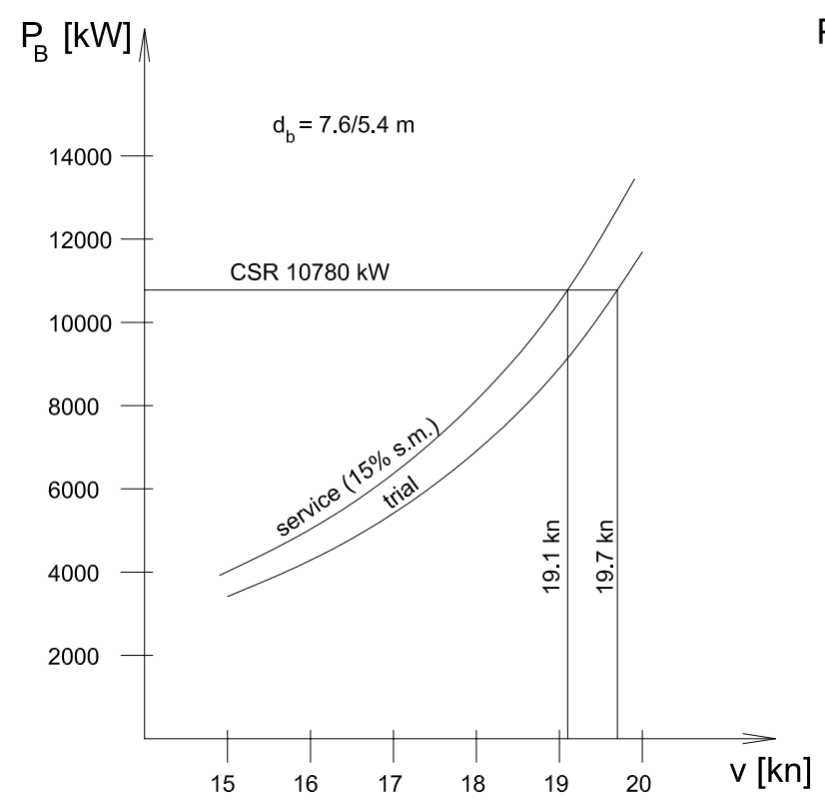

Fig. 7 Speed-Power Estimation of P109 (Container Ship) on Ballast Draught

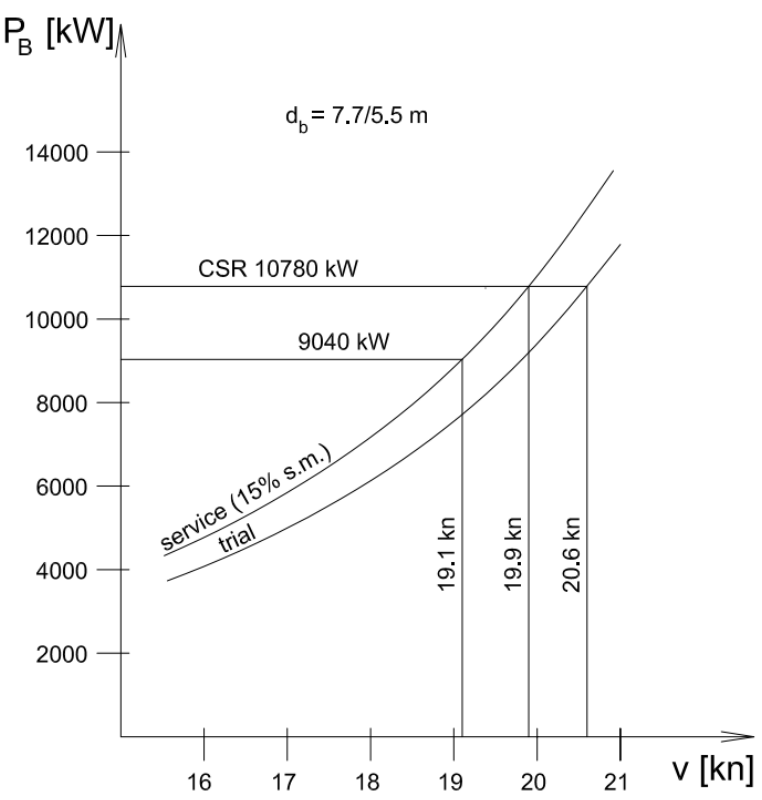

Fig. 8 Speed-Power Estimation of P105 (Reefer Vessel) on Ballast Draught

Calculation of daily fuel oil consumption for both ships is carried out and shown in Table 6. It is based on the declared conditions and needed main engine power for service speed of 19.1 knots.

Table 6 Daily Fuel Oil Consumption when Sailing in Ballast

\begin{tabular}{|l|c|c|c|c|c|c|}
\hline & \multicolumn{3}{|c|}{ P105 (Reefer Vessel) } & \multicolumn{3}{c|}{ P109 (Container Ship) } \\
\hline \multirow{2}{*}{ Consumer } & Power & sfoc & dfoc & Power & sfoc & dfoc \\
\cline { 2 - 7 } & {$[\mathrm{kW}]$} & {$[\mathrm{g} / \mathrm{kWh}]$} & {$[\mathrm{t} / \mathrm{day}]$} & {$[\mathrm{kW}]$} & {$[\mathrm{g} / \mathrm{kWh}]$} & {$[\mathrm{t} / \mathrm{day}]$} \\
\hline Main engine & 9,040 & 158.3 & 34.3 & 10,780 & 162.0 & 41.9 \\
\hline Diesel generator plant & 650 & 192.0 & 3.0 & 650 & 192.0 & 3.0 \\
\hline Total (LCV=42,700 kJ/kWh) & & & 37.3 & & & 44.9 \\
\hline Total (HFO)11 & & & 39.5 & & & 47.6 \\
\hline
\end{tabular}

It can be noticed that there is a significant difference in fuel oil consumption between reefer vessel and container ship. Calculation of fuel oil consumption in the case of an assumed route of 5,000 nautical miles (days in navigation $=5,000 \mathrm{~nm} / 19.1 \mathrm{kn} / 24 \mathrm{~h} /$ day $\approx 11$ days) is as follows. 
Table 7 Total Fuel Oil Consumption when Sailing in Ballast

\begin{tabular}{|l|c|c|c|}
\hline & Duration & $\begin{array}{c}\text { Daily fuel oil } \\
\text { consumption }(\mathrm{dfoc})\end{array}$ & $\begin{array}{c}\text { Total fuel oil } \\
\text { consumption }\end{array}$ \\
\cline { 2 - 4 } & {$[$ days] } & {$[\mathrm{t} /$ day] } & {$[\mathrm{t}]$} \\
\hline P105 (Reefer Vessel) & 11 & 39.5 & $\sim 435$ \\
\hline P109 (Container Ship) & 11 & 47.6 & $\sim 524$ \\
\hline
\end{tabular}

Difference of total fuel consumption is abt. $89 \mathrm{t}$. If we assume a heavy fuel oil price of abt. 400-420 US\$/t, saving of reefer vessel in comparison with container ship is abt. 36,000 US\$ for 11 days sailing in ballast condition.

\subsection{P105 (Reefer Vessel) Sailing at Continuous Service Rating}

Reefer vessel can sail at a higher speed that corresponds to the main engine continuous service rating. In that case, calculation of fuel oil consumption and economy of the voyage differs from previously shown calculation. This case is presented in Table 8.

Table 8 P105 (Reefer Vessel) Daily Fuel Oil Consumption at CSR

\begin{tabular}{|l|c|c|c|c|c|c|}
\hline & \multicolumn{3}{|c|}{ Scantling draught } & \multicolumn{3}{c|}{ Ballast draught } \\
\hline \multirow{2}{*}{ Consumer } & Power & sfoc & dfoc & Power & sfoc & dfoc \\
\cline { 2 - 8 } & {$[\mathrm{kW}]$} & {$[\mathrm{g} / \mathrm{kWh}]$} & {$[\mathrm{t} / \mathrm{day}]$} & {$[\mathrm{kW}]$} & {$[\mathrm{g} / \mathrm{kWh}]$} & {$[\mathrm{t} /$ day $]$} \\
\hline Main engine & 10,780 & 162.0 & 41.9 & 10,780 & 162.0 & 41.9 \\
\hline Diesel generator plant & 3,036 & 192.0 & 14.0 & 650 & 192.0 & 3.0 \\
\hline DG plant during cool. down & 3,736 & 192.0 & 17.2 & & & \\
\hline Total (LCV=42,700 kJ/kWh) & & & 55.9 & & & 44.9 \\
\hline Total: sailing + cool. down & & & 59.1 & & & \\
\hline Total (HFO) & & & 59.3 & & & 47.6 \\
\hline Total: sail.+cool.down (HFO) & & & 62.6 & & & \\
\hline
\end{tabular}

Calculation of fuel oil consumption in the case of an assumed route of 5,000 nautical miles (days in navigation on scantling draught $=5,000$ n.m. $/ 18.7 \mathrm{kn} / 24 \mathrm{~h} /$ day $\approx 11$ days, on ballast draught $=5,000 \mathrm{~nm} / 19.97 \mathrm{kn} / 24 \mathrm{~h} /$ day $\approx 10.5$ days) is given in Table 9 .

Table 9 Total Fuel Oil Consumption when Sailing at Continuous Service Rating

\begin{tabular}{|l|c|c|c|}
\hline \multirow{2}{*}{ P105 (Reefer Vessel) } & Duration & $\begin{array}{c}\text { Daily fuel oil } \\
\text { consumption }(\mathrm{dfoc})\end{array}$ & $\begin{array}{c}\text { Total fuel oil } \\
\text { consumption }\end{array}$ \\
\cline { 2 - 4 } & {$[$ days] } & {$[\mathrm{t} /$ day $]$} & {$[\mathrm{t}]$} \\
\hline \multirow{3}{*}{ Scantling draught } & 1 & 62.6 & 62.6 \\
\cline { 2 - 4 } & 10 & 59.3 & 593 \\
\hline Ballast draught & & & $\sim 656$ \\
\hline
\end{tabular}

In the fully loaded condition the reefer vessel consumes abt. $656 \mathrm{t}$ of HFO (instead of 620 when sailing at a speed of $17.9 \mathrm{kn}$ ) and abt. $500 \mathrm{t}$ of HFO (instead of 435 when sailing at a speed of $19.1 \mathrm{kn}$ ). In this case, still exists significant difference of fuel consumption with respect to the container ship, in fully loaded condition difference is $764-656=108 \mathrm{t}$ of HFO and in ballast condition difference is $524-500=24 \mathrm{t}$ of HFO. At assumed HFO price of abt. 400-420 US\$/t, saving of reefer vessel in comparison with container ship is abt. 44,000 US\$ for sailing in fully loaded condition and abt. 10,000 US\$ in ballast condition 


\section{Final Considerations}

Presented comparison of reefer vessel and container ship dedicated for reefer containers shows that exists significant difference in fuel oil consumption and voyage economics between these two ships. Reefer ship has better speed-power characteristics and lower diesel generator fuel oil consumption in laden condition. The reasons lie in the following basic facts:

- Reefer vessel has significantly lower block coefficient and, consequently, better speed-power characteristics and lower main engine fuel oil consumption

- Large cargo refrigerating plant on reefer vessel has better efficiency than adequate number of small refrigerated FEU aggregates

Advantages of container ship with respect to reefer vessel are also significant and they can be summarized as follows:

- Easier and faster cargo loading and unloading

- Lower price of container ship in relation to reefer vessel

- Easier and less expensive maintenance of cargo holds

Reefer vessel is more energy efficient, it can develop higher speed, so the journey takes less time; on the contrary, cargo loading in the cargo holds takes more time, cargo holds insulation can be damaged during cargo loading/unloading, especially if it is raining.

Container ship can load and unload the cargo faster and easier, but it has lower energy efficiency and, as a rule, it sails at lower speed, so the journey takes more time. It should be kept in mind that the design of a container ship must be adapted to the transportation of refrigerated containers: cargo holds must be equipped with electrical sockets for refrigerated containers, cargo holds must be mechanically ventilated to evacuate the waste heat of refrigerated containers aggregates and diesel generator plant must cover total power consumption, including refrigerated containers and cargo holds ventilation. All this affects the economy of operation of the ship, so it is completely understandable that it is not simple nor easy to choose a better ship type.

When talking about the price of container ship, it should be kept in mind that container ship dedicated to refrigerated containers must be specially designed and is significantly more expensive than "ordinary" container ship (cargo holds mechanical ventilation, "ordinary" container ships do not need mechanical ventilation of cargo holds). Diesel generator plan is several times larger and more expensive than on the "ordinary" container ships to be able to drive refrigerated containers aggregates.

As a conclusion, it could be said that in the carriage of refrigerated cargos container ships may have the advantage when the whole process of cargo transportation is considered, but also, that the economy of reefer vessels' operation is so attractive that further development and improvement of their design can be expected. 


\section{REFERENCES}

[1] LAMB T. Editor: Ship Design and Construction, The Society of Naval Architects and Marine Engineers, Jersey City, 2003.

[2] WATSON, D.G.M., GILFILLAN, A.W.: Some Ship Design Methods, The Naval Architect 4(1976)6, 279-324.

[3] WATSON, D.G.M.: Practical Ship Design, Elsevier Science Ltd, Oxford 1998.

[4] ČUDINA P.: Design Procedure and Mathematical Models in the Concept Design of Tankers and Bulk Carriers, Brodogradnja 59(2008)4, 323-339.

[5] ČUDINA, P: New Methodology in the Basic Design of Merchant Ships, FSB Zagreb, 2010. (in Croatian)

[6] HOU, Y.H., LIANG, X., MU X.Y.: Hull Lines Reliability-Based Optimisation Design, Brodogradnja, 69(2018), 17-33. https://doi.org/10.21278/brod69202.

[7] ČUDINA, P: Analysis of the Energy Efficiency Design Index with a Proposal for Improvement, Brodogradnja 66 (2015)3, 49-59.

[8] STOPFORD, M.: Maritime Economics, $3^{\text {rd }}$ Edition, Routledge, London 2009. https://doi.org/10.4324/9780203891742.

[9] MAGAZINOVIĆ G.: Power Regression Analysis, Ver. 1.0, User's Guide, CADEA, Split, 1997. (in Croatian)

[10] *** Resistance and Propulsion Measurement Results, Ship Model M-1169, Propeller Model V-98, Brodarski Institute, Report No.: 5362-M, Zagreb 1997.

[11] *** Resistance and Propulsion Measurement Results, Ship Model M-1169, Propeller Model V-1018, Brodarski Institute, Report No.: 5405-M, Zagreb 1998.

Submitted: $\quad 3.09 .2018 . \quad$ Predrag Čudina, predrag.cudina@yahoo.com

Accepted: $\quad 5.02 .2019$. $\quad$ Classis Llc Ship Design and Consulting, Rendićeva 18, Split, Croatia 